\title{
Water volume and osmotic behaviour of mouse spermatozoa determined by electron paramagnetic resonance
}

\author{
Junying $\mathrm{Du}^{1,2}$, Jun Tao ${ }^{1}$, F. W. Kleinhans ${ }^{1,2}, \mathrm{P}^{1}$ Mazur $^{3}$ and \\ J. K. Critser ${ }^{1,4,5}$, \\ ${ }^{1}$ Cryobiology Research Institute, Methodist Hospital of Indiana, Indianapolis, IN 46202, USA; \\ ${ }^{2}$ Department of Physics, Indiana University-Purdue University, Indianapolis, IN 46202, USA; ${ }^{3}$ Biology \\ Division, Oak Ridge National Laboratory, Oak Ridge, TN 37831, USA; ${ }^{4}$ Department of Physiology and \\ Biophysics and Obstetrical Gynecology, Indiana University, School of Medicine, Indianapolis, IN 46202, \\ USA; and ${ }^{5}$ Department of Clinical Veterinary Science, Purdue School of Veterinary Medicine, West \\ Lafayette, IN 47907, USA
}

\begin{abstract}
Experiments were conducted to determine the water volume and osmotic behaviour of mouse spermatozoa using an electron paramagnetic resonance technique using the spin label tempone, and the broadening agent potassium chromium oxalate. After a swim-up procedure, an average water volume of $43.3 \mu \mathrm{m}^{3}$ of individual spermatozoa was obtained at 290 mosmol. If a water compartment of $59 \%$ is assumed, the total volume of mouse spermatozoa is $73.4 \mu \mathrm{m}^{3}$. A plot of the relative water volume of mouse spermatozoa versus the reciprocal of buffer osmolality (Boyle van't Hoff plot) is linear in the range 250-900 mosmol of sodium chloride solutions $\left(r^{2}=0.96\right)$. The Boyle van't Hoff plot intercept indicates that $13 \%$ of the spin-label accessible isotonic water is osmotically inactive.
\end{abstract}

\section{Introduction}

An international effort is underway to characterize the genes associated with embryonic development and disease in humans, and the mouse is considered an important model in such studies. An especially powerful approach is to create transgenic animals in which DNA segments of known sequence are inserted into the host DNA. The result has been the creation of a rapidly increasing number of mutant lines, so much so that the maintenance of such lines in standard breeding colonies is becoming a formidable problem. One approach to addressing this problem is the development of a cryopreserved embryo 'bank'. A more cost-effective method would be the cryobiological preservation of mouse spermatozoa.

When cells are subjected to the series of steps involved in cryopreservation, they are subjected to a sequence of strongly anisosmotic conditions. They initially shrink when a cryoprotectant solute is added (creating hyperosmotic conditions), they swell back to near isotonic volume as the cryoprotectant solute(s) permeates, but they then shrink again as water leaves the cell during slow freezing. Finally, after thawing, they undergo severe osmotic changes in volume as the cryoprotectant solute is removed. It is essential to restrict osmotic

\footnotetext{
*Correspondence: Cryobiology Research Institute, Methodist Hospital of Indiana, $1701 \mathrm{~N}$. Senate Blvd, Indianapolis, IN 46202, USA.

Received 28 June 1993.
}

changes to those that are tolerated by the cell to avoid cell damage.

The osmotic response can be calculated if the permeability of the cell to the cryoprotective solute and to water is known. The equations used to estimate the permeability coefficients require a value for the volume of water in an isotonic cell. They also assume that the cell behaves as an ideal osmometer, that is, that the water volume varies linearly with the reciprocal of the osmolality of the external solution (Boyle van't Hoff relationship). The present experiments were designed to determine the isotonic water volume of mouse spermatozoa and test the ideality of the osmotic response of the spermatozoa.

Owing to the highly nonspherical shape of spermatozoa, the measurement of sperm cell volume is more difficult than for other types of cell. In these experiments, an electron paramagnetic resonance (EPR) technique was used in combination with an aqueous spin label, tempone, and a membraneimpermeable broadening agent, potassium chromium oxalate. Tempone labels both the intra- and extracellular water compartments, and the membrane-impermeable broadening agent eliminates the extracellular signal. By measuring the intracellular signal intensity of tempone, the intracellular water volume of the cells can be obtained. This method is independent of cell shape and has been previously used to measure the water volumes of a variety of cell shapes including bull, rabbit and human spermatozoa (Hammerstedt et al., 1978; Gelerinter et al., 1980; Kleinhans et al., 1992), human red blood cells (Moronne et al., 1990) and cyanobacteria (Blumwald et al., 1983).

Downloaded from Bioscientifica.com at 04/26/2023 12:15:23PM 


\section{Materials and Methods}

\section{Materials}

$\left[{ }^{14} \mathrm{~N}\right]$ Tempone(4-oxo-2,2,6,6-tetramethyl-piperidine-1-oxyl) was purchased from Molecular Probes (Eugene, OR). The $\left[{ }^{15} \mathrm{~N}\right]$ tempone (4-oxo-2,2,6,6-tetramethyl-piperidine- $1-{ }^{15} \mathrm{~N}-1$ oxyl) was obtained from MSD Isotopes, Montreal. Potassium chromium oxalate $\left(\mathrm{K}_{3}\left[\mathrm{Cr}\left(\mathrm{C}_{2} \mathrm{O}_{4}\right)_{3}\right] \cdot 3 \mathrm{H}_{2} \mathrm{O}\right)$, referred to here as $\mathrm{CrOx}$, was synthesized according to the procedure of Bailar and Jones (1939). Dulbecco's PBS [pH, 7-7.2; milliosmolality (mosmol), 286] was purchased from GIBCO laboratories (Grand Island, NY). Hoechst 33258, propidium iodide (PI) and 6-carboxyfluorescein diacetate (CFDA) were obtained from Sigma Co (St Louis, MO). The medium used for mouse spermatozoa was PBS supplemented by pyruvic acid (18 $\mu \mathrm{g}$ $\mathrm{ml}^{-1}$, Sigma Co), $60 \%$ DL-lactic acid $\left(2 \mu \mathrm{l} \mathrm{ml}{ }^{-1}\right.$, Sigma Co) and BSA (10 mg ml ${ }^{-1}$, Sigma Co), and referred to as supplemented PBS (S-PBS).

\section{Preparation of mouse spermatozoa}

Ten (Expt 1, isotonic volume measurements) or 35 (Expt 2, osmotic measurements) ICR male mice aged 20-23 weeks (Harlan Sprague Dawley, Indianapolis, IN) were used in this study. The spermatozoa were released into the medium by gently mincing the caudae epididymides and the vasa deferentia. A swim-up procedure was performed by overlaying the

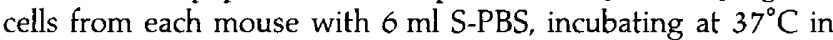
$5 \% \mathrm{CO}_{2}$ and $95 \%$ air for $1 \mathrm{~h}$, and aspirating $5.5 \mathrm{ml}$ of the supernatant. After the swim-up procedure, the cells from each mouse were maintained separately at room temperature and were used within $3 \mathrm{~h}$.

For the osmotic behaviour measurements, the spermatozoa from seven mice were pooled after the swim-up procedure to achieve a sufficient number of cells for the volume measurements at different osmolalities. Approximately 15-20 $\times$ $10^{6}$ cells were obtained after swim-up for each mouse and $80 \%$ of the cells after swim-up were motile (cells counted on a standard haemocytometer under a light microscope).

\section{EPR sample preparation}

Experiment 1: measurement of isotonic water volume. The EPR volume samples were prepared by mixing $2.4 \mu \mathrm{l}$ of $50 \mathrm{mmol}$ $\left[{ }^{14} \mathrm{~N}\right]$ tempone $1^{-1}, 26 \mu \mathrm{l}$ of $115 \mathrm{mmol} \mathrm{CrOx} 1^{-1}$, and $31.6 \mu \mathrm{l}$ of packed spermatozoa in 312 mosmol S-PBS (centrifuged at $500 \mathrm{~g}$ for $10 \mathrm{~min}$ ) in a $5 \mathrm{ml}$ sterile culture tube. The combined solution had a total volume of $60 \mu \mathrm{l}$ with final concentrations of $\left.2 \mathrm{mmol} \mathrm{[}{ }^{14} \mathrm{~N}\right]$ tempone $\mathrm{I}^{-1}, 50 \mathrm{mmol} \mathrm{CrOx} \mathrm{l}{ }^{-1}$, and a total osmotic strength of 310 mosmol. After manually mixing the contents by tapping the tube, $10 \mu \mathrm{l}$ of the sample was transferred to another tube for Hoechst 33258 staining, while another $10 \mu \mathrm{l}$ of the sample were diluted with a precisely known volume (usually $\times 35$ dilution) for the determination of cell concentration in a haemocytometer. The remaining sample was drawn, by capillary action, into a $50 \mu$ disposable micropipette and sealed with Critoseal (Monoject Scientific, St Louis, MO) for EPR measurement.
Experiment 2: measurement of osmotic behaviour. To increase the intensity of the individual EPR lines, $\left[{ }^{15} \mathrm{~N}\right]$ tempone was used for this experiment because the $\left[{ }^{15} \mathrm{~N}\right]$ tempone signal is split into only two lines compared with the three lines from the $\left[{ }^{14} \mathrm{~N}\right]$ tempone signal. The EPR osmotic samples were prepared by mixing $2.6 \mu \mathrm{l}$ of $50 \mathrm{mmol}\left[{ }^{15} \mathrm{~N}\right]$ tempone $\mathrm{I}^{-1}, 13 \mu \mathrm{l}$ of $250 \mathrm{mmol} \mathrm{CrOx} \mathrm{^{-1 }}, 19 \mu \mathrm{l}$ of $\mathrm{NaCl}$ solutions $(0,370,1041$ or 2064 mosmol and $30.4 \mu \mathrm{l}$ packed cells in S-PBS. The mixed solutions had a total volume of $65 \mu \mathrm{l}$, with final concentrations of $2 \mathrm{mmol}\left[{ }^{15} \mathrm{~N}\right]$ tempone $\mathrm{l}^{-1}, 50 \mathrm{mmol} \mathrm{CrOx} 1^{-1}$, and total osmotic concentrations of 290,400,600 and 900 mosmol excluding tempone (Du et al., 1993). The samples with final osmotic strength of $250 \mathrm{mosmol}$ were prepared using the same amount of $\left[{ }^{15} \mathrm{~N}\right]$ tempone and $\mathrm{CrOx}$ as above, $27.4 \mu \mathrm{l}$ of water and $22 \mu \mathrm{l}$ of packed cells (final concentration of $2 \mathrm{mmol}$ $\left[{ }^{15} \mathrm{~N}\right]$ tempone $1^{-1}$ and $\left.50 \mathrm{mmol} \mathrm{CrOx} \mathrm{l}^{-1}\right)$. The final osmotic concentrations were determined by linear addition of the individual osmolalities of the S-PBS, $\mathrm{NaCl}$ and $\mathrm{CrOx}$ (nonpermeating solutes), and were confirmed on a freezing point depression osmometer (Advanced DigiMatic Osmometer, Model 3D2), which yielded agreement within $1 \%$. Cell membrane integrity was determined using dual fluorescent staining with PI and CFDA (Garner $e t$ al., 1986; Noiles $e t$ al., 1993).

A calibration sample was prepared using $2.4 \mu \mathrm{l}$ of $50 \mathrm{mmol}$ $\left[{ }^{14} \mathrm{~N}\right]$ tempone $1^{-1}$ and $57.6 \mu \mathrm{l} \mathrm{S}$-PBS, or $2.6 \mu \mathrm{l}$ of $50 \mathrm{mmol}$ $\left[{ }^{15} \mathrm{~N}\right]$ tempone $\mathrm{I}^{-1}$ and $62.4 \mu \mathrm{l} \mathrm{S-PBS}$ for the isotonic volume and osmotic behaviour measurements, respectively. A broad residual signal remains when extracellular tempone is broadened by $\mathrm{CrOx}$. This is eliminated using digital subtraction of a 'background' reference signal at each osmotic strength. The 'background' reference samples were prepared in parallel with the regular samples, except that the cells were replaced by buffer.

\section{Cell membrane integrity}

For the isotonic volume experiments, $10 \mu \mathrm{l}$ of the EPR sample was mixed with $300 \mu \mathrm{l}$ S-PBS plus $4 \mu$ l Hoechst 33258 $\left(0.01 \mathrm{mg} \mathrm{ml}^{-1}\right.$ stock solution) and allowed to equilibrate for $5 \mathrm{~min}$. Hoechst 33258 is impermeable to the plasma membrane, binds to the DNA in the head of spermatozoa with disrupted membranes, and fluoresces in the blue part of the spectrum. Two to three hours usually elapsed before the fluorescence could be assessed on the flow cytometer; we therefore added $1 \mathrm{ml}$ of 1:100 salmon sperm DNA solution (dissolved in PBS) after $5 \mathrm{~min}$ of staining to bind and remove excess external Hoechst 33258 (Tao et al., 1993) so that the percentage of cells with an intact plasma membrane at the time of EPR measurement could be determined. The percentage of stained cells was determined using both epifluorescence microscopy (200 cells counted) and flow cytometry (5000 cells counted). An epifluorescence microscope (Optiphot, Nikon), equipped with a $365 \mathrm{~nm}$ excitation filter and a $435 \mathrm{~nm}$ barrier filter, was used to distinguish the Hoechst-33258-positive cells. A FACStar Plus Flow Cytometer (Becton Dickinson, San Jose, CA) with a $3 \mathrm{~W}$ Krypton laser operated at $200 \mathrm{~mW}$ power, a UV wavelength of $350 \mathrm{~nm}$, and a barrier filter (450DF65) was used to quantify Hoechst 33258 stains. The Hoechst-33258-negative cells were considered to be membrane-intact cells (Tao et al., 1993).

Downloaded from Bioscientifica.com at 04/26/2023 12:15:23PM 
For the osmotic experiments, CFDA and PI were used because these two fluorescent stains, in combination, assess the status of the membrane in both the head and the tail regions. At each osmolality $10 \mu \mathrm{l}$ of the EPR sample was transferred to $500 \mu \mathrm{l}$ of $\mathrm{NaCl}$ solution at the same osmolality, then $4 \mu \mathrm{l}$ of CFDA (2.5 mg ml ${ }^{-1}$ in dimethylsulfoxide (DMSO) and $10 \mu \mathrm{l}$ PI ( $\mathrm{I} \mathrm{mg} \mathrm{ml}{ }^{-1}$ in $\mathrm{H}_{2} \mathrm{O}$ ) were added to each sample solution. After $5 \mathrm{~min}$ staining, 200 cells were evaluated using fluorescence microscopy. Cells that were CFDA positive and PI negative were considered to be membrane-intact cells.

\section{EPR data acquisition and analysis}

EPR measurements were made at $20 \pm 0.5^{\circ} \mathrm{C}$ on a Varian X-Band E109 spectrometer with a rectangular cavity and an HP9825 data system with custom software for biological spin label work (Kleinhans, 1985).

For isotonic volume measurements, the spectrometer parameters were set as following: power, $20 \mathrm{~mW}$; magnetic field, 3275 gauss; field sweep, 25 gauss; modulation amplitude, 0.5 gauss; amplifier time constant, $0.128 \mathrm{~s}$; and variable rate sweep yielding a total sweep time of $285 \mathrm{~s}$. For the background spectra, the time constant was increased to $0.25 \mathrm{~s}$ and the total sweep time increased to $570 \mathrm{~s}$.

For the osmotic measurements, the spectrometer parameters were: power, $15 \mathrm{~mW}$; magnetic field, 3269 gauss; field sweep, 30 gauss; modulation amplitude, 0.5 gauss; amplifier time constant, $0.064 \mathrm{~s}$; and variable rate sweep yielding a total sweep time of $248 \mathrm{~s}$. For background spectra, the time constant was increased to $0.128 \mathrm{~s}$ and the total sweep time increased to $496 \mathrm{~s}$.

A variable rate sweep was used to improve the signal to noise ratio by spending additional time in the peak regions of the spectrum, with digital signal averaging (Kleinhans, 1985).

\section{EPR water volume measurement}

EPR cell volume measurements for the isotonic volume and the osmotic behaviour were performed using a modification (Kleinhans et al., 1992) of the method of Hammerstedt et al. (1978). Briefly, tempone labels all aqueous regions of the EPR sample, and the membrane-impermeable broadening agent $\mathrm{CrOx}$ is used to eliminate the extracellular tempone signal. The residual extracellular signal of tempone can be eliminated by digital subtraction of the background reference signal from the sample signal. Figure 1 illustrates the process for mouse spermatozoa in 290 mosmol buffer using $\left[{ }^{15} \mathrm{~N}\right]$ tempone. The fractional volume $\left(F_{v}\right)$ occupied by the cell water in the EPR sample can be calculated by dividing the intensity $(I)$ of the intracellular signal by a calibration standard with the same spin label concentration:

$$
F_{v}=I \text { (intracellular) } / I \text { (calibration standard). }
$$

The intensity is given by the equation $I=W^{2} h$, where $W$ and $h$ are the peak-to-peak (PTP) line width and height of the middle field line (or low field line) of $\left[{ }^{14} \mathrm{~N}\right]$ tempone (or $\left[{ }^{15} \mathrm{~N}\right]$ tempone), respectively (Wertz and Bolton, 1972). The

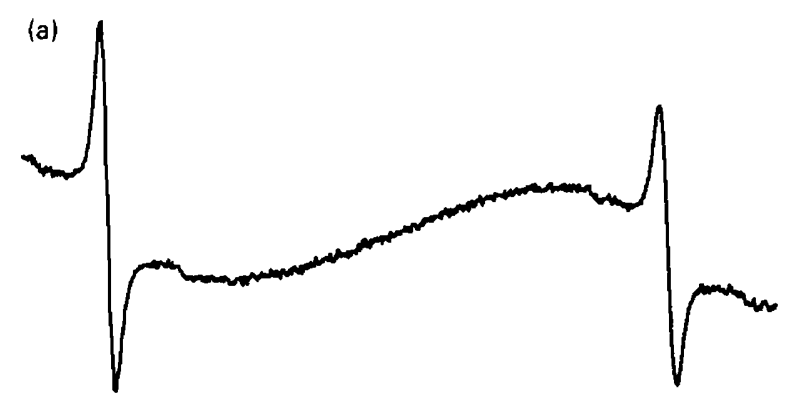

(b)
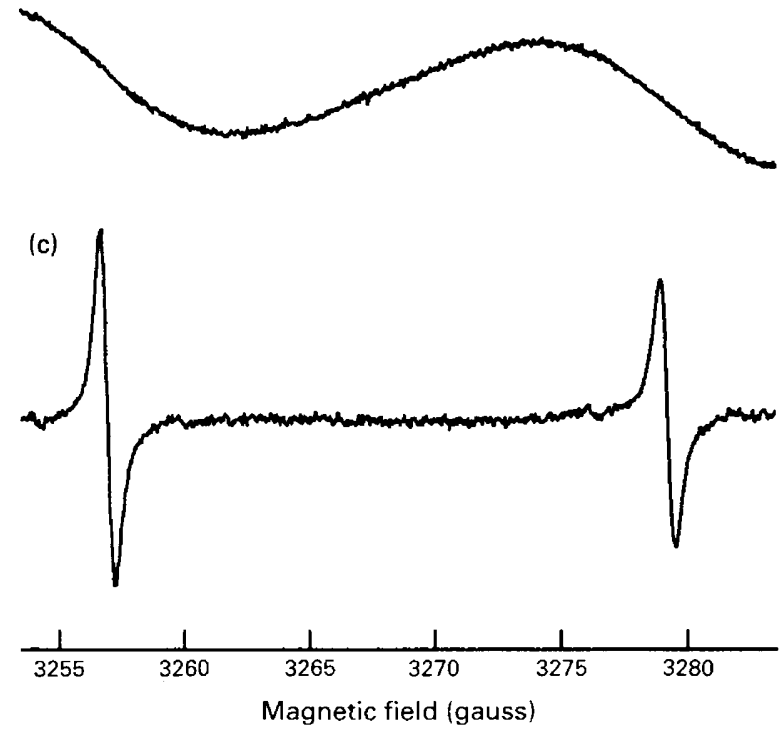

Fig. 1. Electron paramagnetic resonance (EPR) spectra of $\left[{ }^{15} \mathrm{~N}\right]$ tempone-labelled mouse spermatozoa, illustrating the elimination of the residual extracellular background by digital subtraction. All samples contain $2 \mathrm{mmol}\left[{ }^{15} \mathrm{~N}\right]$ tempone $\mathrm{l}^{-1}$ and $50 \mathrm{mmol}$ potassium chromium oxalate $1^{-1}$. (a) Raw spectrum of mouse spermatozoa in 290 mosmol buffer, with a cell concentration of $1.06 \times 10^{8}$ cells $\mathrm{ml}^{-1}$. (b) Background spectrum, buffer only. (c) Intracellular water signal of mouse spermatozoa after digital subtraction of the background spectrum $(c)=(a)-(b)$.

average water volume of a cell $\left(V_{\mathrm{w}}\right)$ is found by dividing the fractional volume by the concentration of membrane-intact cells in the EPR sample $\left(C_{c}\right)$ :

$$
V_{\mathrm{w}}=F_{v} / C_{\mathrm{c}}
$$

For example, if the fractional volume is $4.5 \times 10^{-3}$ and the cell concentration is $1.57 \times 10^{8}$ cell ml ${ }^{-1}, 70 \%$ of which have intact membranes (typical values), Eqn 2 yields a value for the cell water volume of $4.1 \times 10^{-11} \mathrm{ml}$, or $41 \mu \mathrm{m}^{3}$. (The concentration of cells was determined by haemocytometer counts.)

In the isotonic volume measurement experiments, the percentage of membrane-intact cells was taken to be the percentage that stained negatively for Hoechst 33258. During these experiments, the rotational correlation time $\left(\tau_{c}\right)$, which is a measure of the cytoplasmic microviscosity, was also obtained (Keith and Snipes, 1974; Hammerstedt et al,, 1978; Morse, 1986). 
Table 1. Summary of mouse sperm water volume and the percentage of membrane-intact cells at 310 mosmol from ten mice

\begin{tabular}{|c|c|c|c|c|}
\hline & $\begin{array}{l}\text { Water volume } \\
\qquad\left(\mu \mathrm{m}^{3}\right)\end{array}$ & $\begin{array}{l}\text { Percentage of } \\
\text { intact cells } \\
\text { (microscopy) }\end{array}$ & $\begin{array}{l}\text { Percentage of } \\
\text { intact cells } \\
\text { (FACS) }\end{array}$ & $\begin{array}{l}\text { Percentage of } \\
\text { intact cells } \\
\text { (Mean) }\end{array}$ \\
\hline & 42.7 & 67 & 74.4 & 70.7 \\
\hline & 43.1 & 72 & 76.7 & 74.3 \\
\hline & 34.5 & 76 & 66.2 & 71.1 \\
\hline & 35.4 & 76 & 76.0 & 76.0 \\
\hline & 43.7 & 75.5 & 75.5 & 75.5 \\
\hline & 38.9 & 72 & 68.0 & 70.0 \\
\hline & 37.2 & 58 & 58.4 & 58.2 \\
\hline & 38.6 & 78 & 67.9 & 73.0 \\
\hline & 37.1 & 69 & 75.5 & 72.3 \\
\hline & 41.1 & 65 & 63.3 & 64.1 \\
\hline Mean & 39.2 & 70.8 & 70.2 & 70.5 \\
\hline SD & 3.3 & 6.2 & 6.3 & 5.5 \\
\hline
\end{tabular}

${ }^{\mathrm{a}, \mathrm{b}}$ Hoechst-33258-negative cells.

${ }^{\mathrm{c}}$ Mean of the microscopy and FACS values.

FACS: fluorescence-activated cell sorter.

For the osmotic behaviour experiments, the CFDA-positive, PI-negative cells were considered to be membrane-intact cells. Cell volumes were normalized to 290 mosmol (Du et al., 1993). The Boyle van't Hoff relationship is generated by plotting the normalized spermatozoa volume against the reciprocal osmolality; that is, 290 divided by the final osmotic concentrations. In replicate experiments, the sequence of exposure to high tonicity and low tonicity solutions was reversed to avoid any systematic effects of time.

\section{Boyle van't Hoff relationship}

Cells are considered to exhibit ideal osmotic behaviour if they obey the following Boyle van't Hoff relationship:

$$
V_{\mathrm{w}}=V_{\mathrm{i}}\left(M_{\mathrm{i}} / M\right)+V_{\mathrm{a}}
$$

where $V_{\mathrm{w}}$ is the total volume of cell water at osmolality $M, V_{\mathrm{i}}$ is the volume of osmotically active water at the isotonic osmolality $M_{\mathrm{i}}$, and $V_{\mathrm{a}}$ is the volume of osmotically inactive (but tempone-accessible) water. This can be normalized by dividing by the total cell isotonic water, $V_{\mathrm{wi}}=V_{\mathrm{i}}+V_{\mathrm{a}}$, yielding:

$$
y=V_{\mathrm{w}} / V_{\mathrm{wi}}=V_{\mathrm{i}} / V_{\mathrm{wi}} \cdot\left(M_{\mathrm{i}} / M\right)+V_{\mathrm{z}} / V_{\mathrm{wi}}
$$

which is the form used here. Then, when the normalized water volume is plotted against reciprocal osmolality, the $y$ axis intercept is the fraction of osmotically inactive water, $V_{\mathrm{a}} / V_{\mathrm{wi}}$, which is accessible by tempone. The proportions of osmotically active and inactive water are sometimes reported in terms of a Ponder's R, defined as the ratio of the osmotic water divided by the total water in an isotonic cell (Dick, 1966). In terms of $\mathrm{R}$, Eqn 4 can be written as:

$$
y=\mathrm{R}\left(M_{\mathrm{i}} / M\right)+(\mathrm{I}-\mathrm{R}) .
$$

\section{Morphometric volume determination}

A rough morphometric estimate of the mouse sperm volume was made using data from Cummins and Woodall (1985) for the species Mus musculus (house mouse) along with estimates made by microscope in this laboratory. Averaging the data reported by Cummins and Woodall a mean head length (hl) of $8.4 \mu \mathrm{m}$, a head width (hw) of $3.65 \mu \mathrm{m}$, a midpiece length (ml) of $22.1 \mu \mathrm{m}$, a midpiece diameter ( $\mathrm{md}$ ) of $1.3 \mu \mathrm{m}$, and a principal piece length (pl) of $96 \mu \mathrm{m}-6 \mu \mathrm{m}$ of tail-end $=90 \mu \mathrm{m}$ were obtained. Examination by microscope gave an average thickness for the head $(t)$ of $0.8 \mu \mathrm{m}$, a principal piece diameter (pd) of $0.65 \mu \mathrm{m}$, a tail-end length ( $\mathrm{tl}$ ) of $6 \mu \mathrm{m}$, and a tail-end diameter ( $\mathrm{td}$ ) of $0.2 \mu \mathrm{m}$. The tail-end estimates are very approximate, but fortunately the tail-end makes only a negligible contribution to the volume. These were combined in the following simple geometric fashion to estimate the morphometric volume:

$$
\begin{aligned}
\begin{array}{l}
V=0.88 \cdot \mathrm{hl} \cdot \mathrm{hw} \cdot \mathrm{t}+\pi \cdot(\mathrm{md} / 2)^{2} \cdot \mathrm{ml} \\
+\pi \cdot(\mathrm{pd} / 2)^{2} \cdot \mathrm{pl}+\pi \cdot(\mathrm{td} / 2)^{2} \cdot \mathrm{tl},
\end{array} &
\end{aligned}
$$

yielding a $V$ value of $81 \mu \mathrm{m}^{3}$. The formula is self explanatory except for the factor of 0.88 . The cross-sectional area of the head is taken to be the width times the length times a geometrical factor correcting for the non-rectangular shape of the head. The geometrical factor is estimated to be 0.88 from the cross-sectional figures produced by Eddy (1988).

\section{Statistical analysis}

Data are expressed as means $\pm \mathrm{SD}$. Statistical analysis for the data concerning the Hoechst 33258 stain from the microscopy and flow cytometry counts were carried out by a paired Student's $t$ test. 

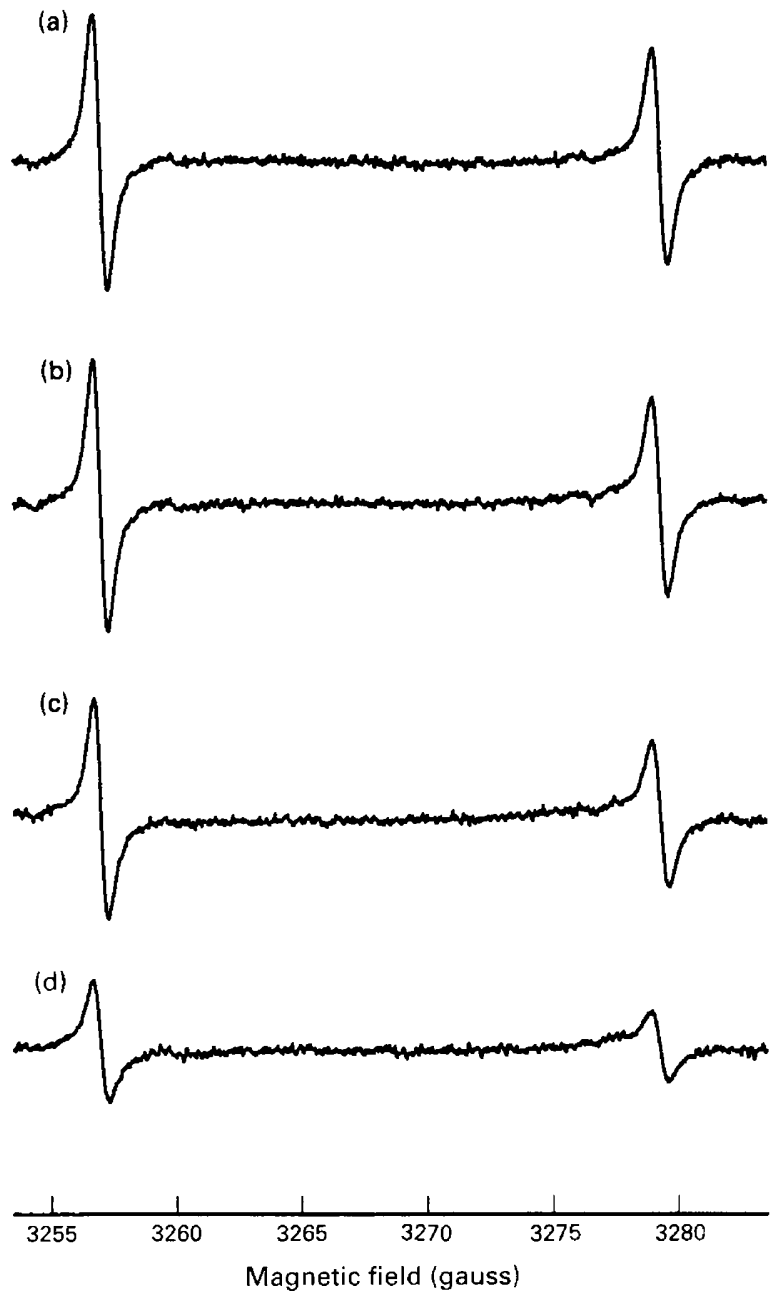

Fig. 2. Typical electron paramagnetic resonance (EPR) spectra (after background subtraction) of mouse spermatozoa in different osmotic strength buffers. Varian E109 console gain, $1 \times 10^{4}$; filter time constant, $0.064 \mathrm{~s}$; field modulation, 0.5 gauss; variable sweep speed (see text); $\left[{ }^{15} \mathrm{~N}\right]$ tempone, $\left.2 \mathrm{mmol}\right]^{-1}$; potassium chromium oxalate, $50 \mathrm{mmol} \mathrm{l}^{-1}$. The EPR signal intensity depends on both the cell volume and the cell concentration. Fewer cells were used in the 250 mosmol sample. Mouse spermatozoa at (a) 250 mosmol, with a cell concentration of $0.73 \times 10^{8}$ cells ml $^{-1}$, (b) 400 mosmol, with a cell concentration of $0.91 \times 10^{8}$ cells ml $\mathrm{ml}^{-1}$, (c) 600 mosmol, with a cell concentration of $1.32 \times 10^{8} \mathrm{cells} \mathrm{ml}^{-1}$, and (d) $900 \mathrm{mosmol}$,

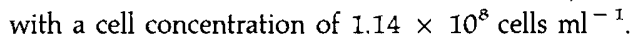

\section{Results}

\section{EPR measurements}

The intracellular water volumes of mouse spermatozoa at 310 mosmol from ten mice are listed in Table 1 . The mean water volume was $39.2 \pm 3.3 \mu^{3}$ ( $\pm \mathrm{SD}$ ), which (with linear extrapolation shown to be valid below) is equal to $41.6 \pm 3.5 \mu \mathrm{m}^{3}$ at 290 mosmol; the osmolality that is considered isotonic. The water volume of mouse spermatozoa obtained by the osmotic experiment at $290 \mathrm{mosmol}$ was $45.0 \mu^{3}$. Taking the average of these two results, a water volume of $43.3 \mu \mathrm{m}^{3}$ is obtained. Assuming the cell water volume of spermatozoa is $59 \%$ of the

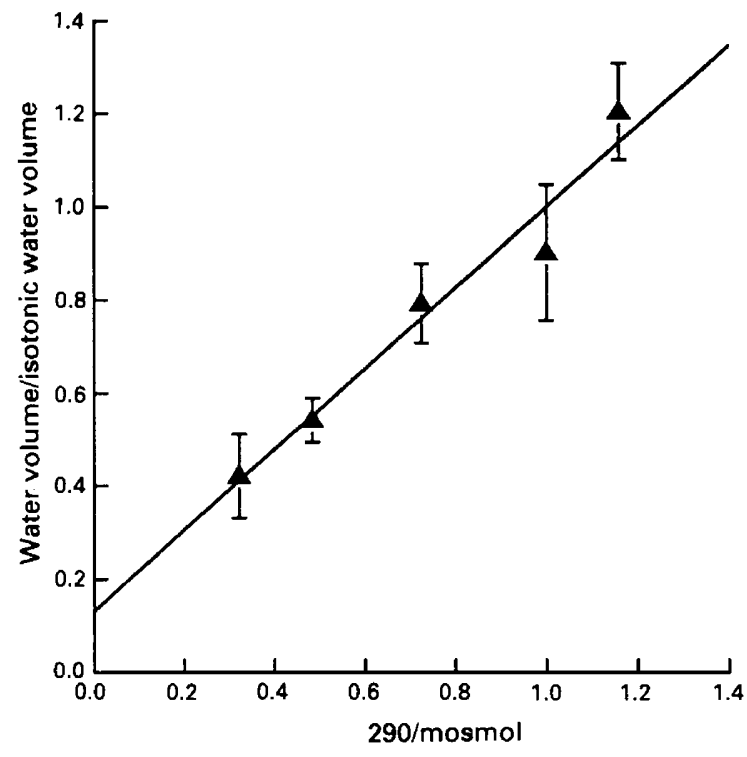

Fig. 3. Osmotic (Boyle van't Hoff) response of mouse spermatozoa. Relative water volume of mouse spermatozoa (determined by electron paramagnetic resonance) versus reciprocal buffer osmolality in the range $250-900$ mosmol is shown (cell volumes were normalized to 290 mosmol) (mean $\pm \mathrm{SD}, n=5$ ). Least squares fit yields: $y=0.867 x+0.133 ; r^{2}=0.960$.

total (as for humans; Kleinhans et al., 1992), the total cell volume is $73.4 \mu^{3}$ at 290 mosmol. This assumption of $59 \%$ water may not be the most appropriate value for mouse spermatozoa since these cells are much larger and have different morphology from human and bovine spermatozoa; however, a better value is not available.

Typical EPR spectra (after background subtraction) of mouse spermatozoa in buffer ranging from 250 to 900 mosmol are shown in Fig. 2. A plot of the relative water volume of mouse spermatozoa versus the reciprocal of the external osmolality (Boyle van't Hoff plot) is shown (Fig. 3). A least squares fit generates a straight line $\left(y=0.867 x+0.133 ; r^{2}=0.960\right)$.

The intracellular microviscosity of mouse spermatozoa at 290 mosmol is 4.35 times the microviscosity of isotonic buffer.

\section{Cell fragility}

The Hoechst 33258 staining results from fluorescence microscopy and flow cytometry indicated an average of $70 \%$ of cells had intact membranes in isotonic EPR samples. Table $I$ lists the percentage of membrane-intact cells from fluorescence microscopy and flow cytometry. A paired Student's $t$ test showed no significant difference $(P>0.05)$ between these two analytical methods.

The fluorescence microscope CFDA-PI staining results showed that the percentage of membrane-intact cells in the osmotic samples remained constant in the $250-900$ mosmol range at approximately $65 \pm 5 \%$ (Table 2 ).

\section{Discussion}

The EPR measurements yield a value of $43.3 \mu \mathrm{m}^{3}$ for the volume of water in the isotonic mouse spermatozoa. If, as in Downloaded from Bioscientifica.com at 04/26/2023 12:15:23PM 
Table 2. Summary of the percentage of mouse spermatozoa with intact membranes at different osmolalities

\begin{tabular}{ll}
\hline Osmolality (mosmol) & Mean $\pm \mathrm{SD}^{\mathrm{a}}$ \\
\hline 900 & $64.2 \pm 4.4$ \\
600 & $66.0 \pm 4.9$ \\
400 & $65.6 \pm 5.1$ \\
290 & $65.2 \pm 7.6$ \\
250 & $62.4 \pm 5.2$ \\
\hline
\end{tabular}

${ }^{2} n=5$.

the spermatozoa of other mammals, that represents $59 \%$ of the total cell volume (Kleinhans et al., 1992), then the estimated total mouse sperm volume is $73.4 \mu^{3}$. This value agrees well with a morphometric volume estimation of $81 \mu \mathrm{m}^{3}$ made using dimensional data from our laboratory and data reported by Cummins and Woodall for house mouse spermatozoa (1985). These values for the water and total volumes of mouse spermatozoa are about twice that of human (Kleinhans et al., 1992) and bovine spermatozoa (Hammerstedt et al., 1978).

Contamination with cytoplasmic droplets may inflate our EPR volume measurements slightly. We estimate the potential size of this error as follows. The concentration of cytoplasmic droplets is estimated to be equal to $40 \%$ of the number of spermatozoa. Under the microscope the droplets appear slightly smaller than human droplets, which we estimate to have a volume of $9 \mu \mathrm{m}^{3}$ (Kleinhans et al., 1992). Assuming a droplet volume of $7 \mu \mathrm{m}^{3}$ consisting of $75 \%$ water yields a small correction to the mouse sperm water volumes of $\Delta \mathrm{V}=-0.4 \times 0.75 \times 7 \mu \mathrm{m}^{3}=-2 \mu \mathrm{m}^{3}$. This yields corrected mouse sperm volumes of $41.3 \mu \mathrm{m}^{3}$ aqueous and $70.0 \mu \mathrm{m}^{3}$ total. Because of the uncertainties in this correction and its small size relative to the standard deviation of the volume measurements, we have not applied this correction to our reported volume values.

The relative intracellular viscosity of mouse spermatozoa is similar to the value of the human red blood cell, 4.63 (Morse, 1986), but, for unknown reasons, it is about twice the value for human spermatozoa, which is 1.98 (Du et al., 1993).

The membrane damage observed in the EPR samples reflects cell death with time, the effects of sample preparation handling, and a suboptimal buffer environment with $\mathrm{CrOx}$ and, in the case of the osmotic samples, anisotonic conditions. Osmotic stress, by itself, is not a major factor since the percentage of cells with intact membranes remains constant at approximately $65 \%$ in the range $250-900 \mathrm{mosmol}$. In similar experiments with human spermatozoa, more than $90 \%$ of cells had intact membranes over the same range of osmolalities ( $\mathrm{Du}$ et al., 1993) - a fact that may suggest that mouse spermatozoa are more fragile than are human spermatozoa.

The linearity of the Boyle van't Hoff plot indicates that mouse spermatozoa act as ideal osmometers over the range 250-900 mosmol $\mathrm{NaCl}$. The results reported here show a tempone-accessible, osmotically inactive component of intracellular water that equals $13 \%$ of the isotonic water volume of mouse spermatozoa. This percentage of osmotically inactive water is the same as that found for human spermatozoa (Du et al., 1993). If the intercept of 0.13 is expressed in terms of Ponder's $R$, a value of 0.87 is obtained. This $R$ is similar to the values reported for red blood cells (0.78-0.92) (Dick, 1966).

In conclusion, a shape-independent method, EPR, was used to determine the isotonic water volume, the fraction of osmotic water, and the osmotic response of mouse spermatozoa. These data provide a foundation for the development of a fundamental cryobiological understanding of mouse spermatozoa. They are needed for the determination of membrane water permeability (Lp) and cryoprotectant permeability (Ps), with which it is possible to model water loss during freezing and thereby to calculate optimal freezing protocols for the cryopreservation of mouse spermatozoa.

This work was supported by grants from the Methodist Hospital of Indiana, the NIH (KO4-HD00980), and the Office of Health and Environmental Research, US Dept of Energy, with Martin-Marietta Energy Systems. The article was written by a contractor of the US government under contract No. DE-AC05-84OR21400 and, accordingly, the US government retains a nonexclusive, royalty-free licence to publish or reproduce the published form of this contribution, or allow others to do so, for US government purposes.

\section{References}

Bailar JC, Jr and Jones EM (1939) Trioxalato salts Inorganic Synthesis 1 35-38

Blumwald E, Mehlhorn RJ and Packer L (1983) Studies of osmoregulation in salt adaptation of cyanobacteria with ESR spin-probe techniques Proceedings of the National Academy of Science USA $802599-2602$

Cummins JM and Woodall PF (1985) On mammalian sperm dimensions Journal of Reproduction and Fertility 75 153-175

Dick DAT (1966) Cell Water pp 44-76. Butterworths, Washington DC

Du Junying, Kleinhans FW, Mazur P and Critser JK (1993) Osmotic behavior of human spermatozoa studied by EPR Cryo-Letters 14 285-294

Eddy EM (1988) The Spermatozoon. In The Physiology of Reproduction Vol 1 pP 27-68 Eds E Knobil, JD Neill, LL Ewing, GS Greenwald, CL Markert and DW Pfaff. Raven Press, New York

Garner DL, Pinkel D, Johnson LA and Pace MM (1986) Assessment of spermatozoal function using dual fluorescent staining and flow cytometric analysis Biology of Reproduction 34 127-138

Gelerinter E, Narra S and Killian GJ (1980) Effect of ejaculation frequency on the water volume of rabbit spermatozoa as determined by electron spin resonance spectroscopy Biology of Reproduction 23 513-517

Hammerstedt RH, Keith AD, Snipes W, Amann RP, Arruda D and Griel LC, Jr (1978) Use of spin labels to evaluate effects of cold shock and osmolality on sperm Biology of Reproduction 18 686-696

Keith AD and Snipes W (1974) Viscosity of cellular protoplasm Science 183 666-668

Kleinhans FW (1985) A noise-reduction scheme for computer-controlled EPR spectrometers Journal of Magnetic Resonance 65 146-148

Kleinhans FW, Travis VS, Du Junying, Villines PM, Colvin KE and Critser JK (1992) Measurement of human sperm intracellular water volume by ESR Journal of Andrology 13 498-506

Moronne MM, Mehlhorn RJ, Miller MP, Ackerson LC and Macey RI (1990) ESR measurement of time-dependent and equilibrium volumes in red cells Journal of Membrane Biology 115 31-40

Morse PD, Il (1986) Determining intracellular viscosity from the rotational motion of spin labels Methods in Enzymology 127 239-249

Noiles EE, Mazur P, Watson PF, Kleinhans FW and Critser JK (1993) Determination of water permeability coefficient for human spermatozoa and its activation energy Biology of Reproduction 48 99-109

Tao Jun, Critser ES and Critser JK (1993) Evaluation of mouse sperm acrosomal status and viability by flow cytometry Molecular Reproduction and Development $36 \quad 183-194$

Wertz JE and Bolton JR (1972) Electron Spin Resonance: Elementary Theory and Practical Applications. McGraw-Hill, New York

Downloaded from Bioscientifica.com at 04/26/2023 12:15:23PM 